DOI: $10.20472 / T E .2020 .8 .2 .004$

\title{
LABOUR RELATIONS AMONG ZIMBABWEAN TEACHERS: WELLBEING AND THE CHALLENGES OF PROFESSIONALISM
}

\section{LLOYD CHAURIKA MABHOYI}

\begin{abstract}
:
This study investigates teachers' views on the quality of their wellbeing through analysis of teacher narratives in relation to salaries as reflected by teachers' community standing and access to daily essentials. Through snowballing, seventeen participants were identified from the current and the recently resigned. The teachers answered researcher-led open-ended questions. The researcher recorded individual narratives and used these in textual analysis to establish teachers' experiences and perceptions of their wellbeing. The results of this limited study confirm that the sampled Zimbabwean teachers are underpaid, unhappy with their salaries causing teachers to worry about their wellbeing in this economically struggling Sub-Saharan state.
\end{abstract}

\section{Keywords:}

teacher wellbeing, Equity Theory, salary, poverty, inflation, bad money, teacher trade unionism, Zimbabwe

JEL Classification: 100, 124, D69

\section{Authors:}

LLOYD CHAURIKA MABHOYI, College of Education, University of South Africa, Pretoria, South Africa, Email: 8735409@mylife.unisa.ac.za

\section{Citation:}

LLOYD CHAURIKA MABHOYI (2020). Labour relations among Zimbabwean teachers: Wellbeing and the challenges of professionalism. International Journal of Teaching and Education, Vol. VIII(2), pp. 53-76., 10.20472/TE.2020.8.2.004 


\section{Introduction}

While a great deal of publicity has been given to the perennial labour issue of Zimbabwean teachers' remuneration-related strikes, very little, if any, attention has been given to investigating the teachers' personal narratives about their salary-related wellbeing experiences. According to McCallum, Price, Graham and Morrison, wellbeing has no clearcut definition according to the available literature as studies tend to emphasise various aspects of teacher wellbeing factors. The preferred definition of this study highlights the diverse and fluid nature of respect for the individual as to how a teachers' salary affects the teachers' family livelihood, community beliefs about teacher status, values, culture, professional experiences, opportunities and contexts across time and change for positive and unique notions, among teachers (McCallum et al, 2017). This view of teacher wellbeing builds on the teacher concerns with wellbeing, which are self-efficacy, job satisfaction, organisational climate, burnout and stress (Ereaut and Whiting, 2008) for a definition as earlier presented by Forgeard, Jayawickreme, Kern \& Seligman, (2011) who income, goods and political circumstances among the factors of a teachers' wellbeing.

This study views wellbeing as synonymous with workers' welfare, emphasising salary-related happiness, contentment and one's standard of living in financial and material ways, but cognisant of the fact that teachers have a variety of tastes relating to these difficult-to-measure aspects of wellbeing (Böhm-Bawerk, 2018). Guiding that is the notion that before becoming a teacher, one is a human being to their wishes and needs... and also have concern with their own survival, (Hunger, Morosini and Stobaus, 2016).

Wellbeing experiences for teachers relate to how they feel and function, and how they evaluate their lives (Thomson, 2014). Perceived non-consideration of the value of teachers' wellbeing experiences may be propelled by the prejudiced stance that continued practice as a teacher in Zimbabwe was akin to taking some pietism/vow of poverty (Scott, in Gee, 2017). In any case, traditionally, conservative thinking posits that a salary on its own is not all that can motivate teachers but the desire to serve. However, there appears to be evidence to the effect that, indeed, a salary presents a possibly significant additional reward that can motivate teachers and their behaviour in any school (Oshagbemi, 2000). It could be argued that teacher wellbeing is deeply connected to the quality of their work hence the CESE, (2014)'s acknowledgement that teachers are the most important in-school factor contributing to student success, satisfaction and achievement. Teachers with poor feelings about their wellbeing are therefore probably not the best custodians of the desired student success, one may postulate. The Indonesian government's rationale for a large 90th percentile salary increase was to improve teacher wellbeing by achieving raised teacher morale, motivation and job satisfaction to boost teacher effort for student learning, according to Ree, Menno Pradhan, Rogers and Muralidharan (2018). The link between a teacher's salary in how that fulfils feelings about their wellbeing may probably be at the core of a teacher's commitment to on-the -job effectiveness/student learning.

The adopted definition of a salary here is from Chaudhry, Sabirb, Rafi and Kalyarc (2017) and $\mathrm{Li}$ (2013), who define a salary as some form of episodic compensation paid by the Zimbabwe Government, (ZimGov) in the form of currency to teachers according to the signed employment contract. Accordingly, the purpose of this study is to explore the teachers' main 
wellbeing concerns and advise government rewards policy from answering these research questions:

1. What are teachers' personal experiences of their salaries?

2. Do teachers have any issue/s with their remuneration?

3. Is it an advantage to be a teacher in contemporary Zimbabwe?

4. What are the teachers' expectations from their employer?

5. Do teachers' have any advice for their government's rewards policy?

\section{Literature review}

Teacher wellbeing themes seem to have remained consistent with little incremental changes since the 1950's. Symonds and Ford (1952) argued that teacher welfare issues must include an analysis of teachers' economic security, professional adequacy, personal security, and working conditions and viewed these as critical for meaningful debate as well as the teaching/learning relationship. The above themes are prevalent in currently developing literature (Ree, et al., 2018) in Zimbabwe. Moyo (1996), explored the place of the then main trade 'union', the Zimbabwe Teachers' Association (ZIMTA), relating to teachers' professional and wellbeing issues. ZIMTA does not seem to have a great history of supporting the teachers' call to strike when necessary for improved teacher wellbeing (United States Department of State, 2003). Probably due to historical 'quisling' perceptions, ZIMTA's teacher representation monopoly on teacher wellbeing has now been challenged by liberalisation, as confirmed by Majongwe (2019), who stated that Zimbabwe had more than 20 registered unions.

By 2015, ZIMTA was increasingly becoming more worker wellbeing representative, as evidenced by its demand for salary reinstatement for 1,000 teachers who had been removed from the payroll (Gande, 2015) and, in February 2019, ZIMTA collaborated with the Progressive Teachers' Union of Zimbabwe (PTUZ) to announce the start of a teacher's strike on 5 February 2019 (Lovemore, 2019). The new unions, as observed by Macleod (2016), are becoming more and more militant in their attempts to achieve guaranteed entitlement to a decent salary that should not have to include extra tuition/second jobs for financial freedom from a life of drudgery and servitude (Macleod, 2016). Hunger et al, (2016) confirms the same by alluding to the fact that teachers are not immune to the pressures of a consumer society needing other sources of income and/or other jobs.

Anecdotal reports seem to confirm a perennial clash and failure of negotiations (BBC, 2016; Claude, 2013; Eyewitness News [EWN], 2019; Tafirenyika, Muvundusi \& Chiketo, 2019; Xaxa, 2018) between ZimGov and its teaching human capital relating to salary issues in Zimbabwe. This has resulted in teacher salaries becoming a major subject in the Zimbabwean '...political economy of labour relations' (Barnetson, 2010:4), and is largely understood to be negatively affecting teachers' wellbeing. However, there does not seem to be any research interest in the Zimbabwean-specific issue of teacher salaries being a central factor of their wellbeing. ZimGov has remained intransigent to the teachers' need for decent remuneration in what is probably an effort to keep teachers neutralised by poverty and alienated as an intelligentsia class. In Russia, the government created a hatred for the intelligentsia because this group of citizens was perceived to be preoccupied with democratic and socialist debates, the accursed questions for dictatorships (Mandel, 2017). 
Sibanda (2002) views ZimGov as repressive and hypocritical with regard to worker relations matters and being even worse than the old colonial master in worker relations matters. Chimhini (1994) noted that ZimGov had tended to neglect real trade union issues relating to fair civil service collective salary bargaining, and suppressed the right to strike. Real trade union issues are pertinent to any worker's wellbeing, particularly the salary question under hyperinflationary economic situations.

Although the Indonesian government had hoped that increased teacher salaries would increase time spent on the job by teachers, the results of Ree, et al's (2018) study confirmed that higher salaries improved the wellbeing of teachers but with no corresponding teacher effectiveness. Probably, Zimbabwean teachers would prefer to share the Indonesian government's generosity. These teachers appear to be earning worthless salaries that have been eroded as a result of the last inflation episode of 14 September 2017, according to Hanke (2019), due to the Zimbabwe dollar again triggering hyperinflation, as illustrated in the graph below.

\section{Zimbabwe's Implied Annual Inflation Rate}

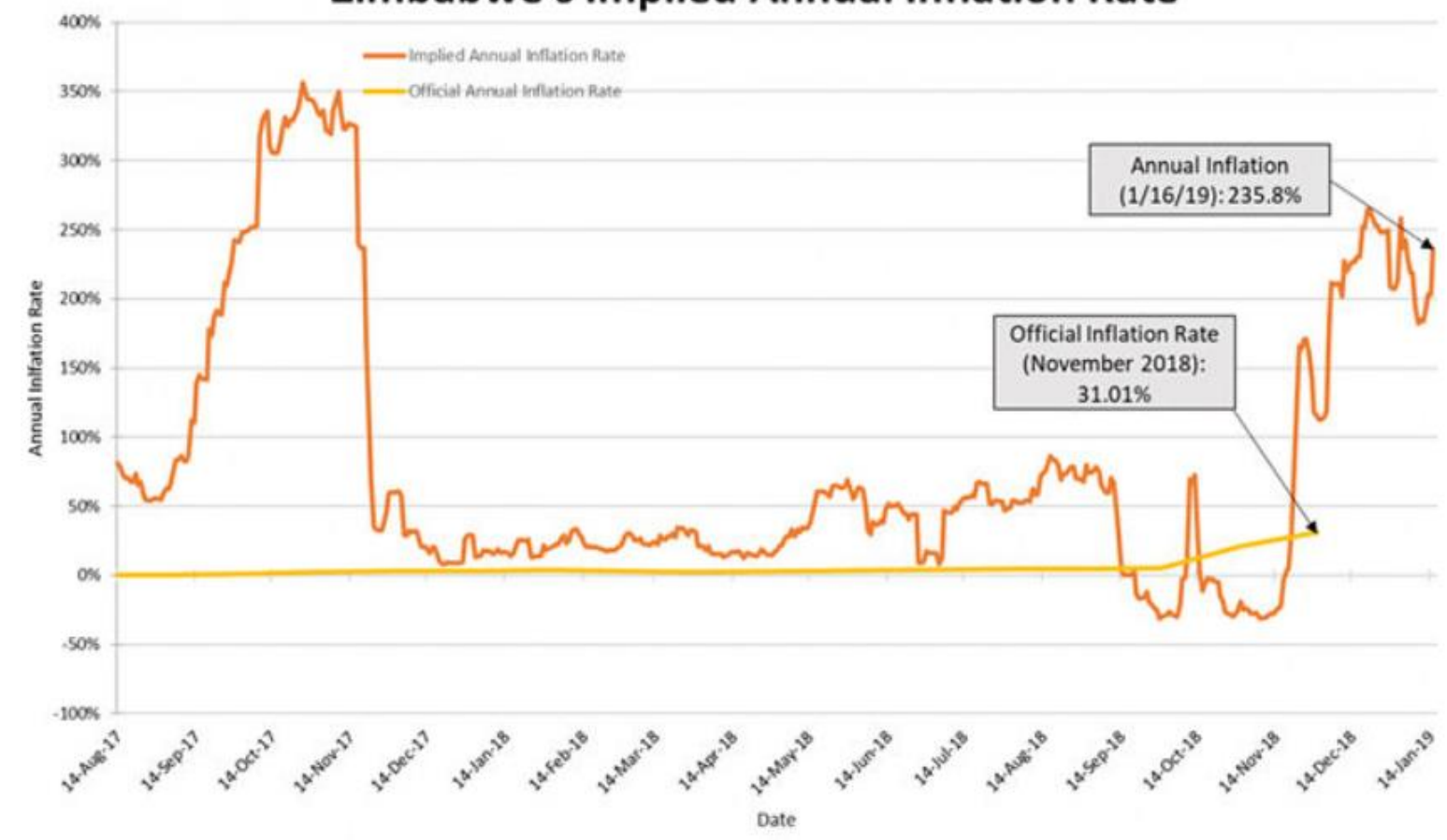

Adapted from Hanke (2019)

Zimbabwean teachers are officially supposed to be paid in US dollars (US\$) but their salaries are only accessible as Bond Notes and Real Time Gross Settlement (RTGS). The US\$ is as good as the Bond Note in that both are just government unbacked printed money to finance deficits (and therefore actually bad money) (Ghizoni, 2013), but the Zimbabwean Bond Note is vulnerable to hyperinflation against the US\$ since bad money cannot compete against good money in the same market circulation, according to Gresham's Law of the Monetary Systems.

During the time of this research, the inflation rate in Zimbabwe was above $235.8 \%$, and the black-market rate source of the US\$ consistently hovered above 3 Bond Notes to 1 US\$. ZimGov states that this artificial currency trades on a ratio of 1:1 with the US $\$$ but "Bad money drives out good", posits Hanke (2019). 
Teachers' experiences are that their wages shrink further due to the fact that, in practice, the prices of common goods for purchase are officially quoted in US\$ but are trebled if the buyer has Bond Notes, and this reduces teachers' buying power.

Teacher salaries in Zimbabwe have been low for a very long time. The exacerbating effect of the 'bond' form of salary (unbacked currency) (Macleod 2016) and additional taxes are generally viewed as forms of state dishonesty and covert theft from teachers (Macleod, 2016). The fact that teachers' salaries were low and were further diminished relating to purchasing points were challenges for teachers based on the logical argument that the highest teacher salary in Zimbabwe was $\$ 503.00$ per month against a poverty datum line of $\$ 539.00$ (Taruvinga, 2018). That salary only had the buying power of a mere $\$ 168.00$ after tax. Furthermore, these salaries are not inflation risk protected (McMahon, 2018). Eggers and Calegari (2011) confirmed that teacher salaries were low compared to other jobs that required either college training or a degree. This was reiterated by Chireshe and Shumba (2011) and Gomba (2015), who further concluded that teachers in Zimbabwe were frustrated by low salaries in this hyperinflationary economy. It appears that teachers in Zimbabwe feel shortchanged (Taruvinga, 2018) and therefore frustrated into taking industrial action against ZimGov's salary policy, which does not fairly reflect teacher input.

\section{Reciprocity and gift exchange}

ZimGov's salary position policy contradicts the models of reciprocity and gift exchange, as explained by Kube, Marechal and Puppe (2012) and by Ree, et al. (2018). These models suggest that teachers are capable of paying back with an effort premium if they are paid decent wages. It should be noted that, when an employer pays a poor salary, it becomes challenging for that employer to demand high productivity and adherence to professionalism.

A teacher's desire to work according to their work ethic is further compromised when what appear to be genuine wellbeing concerns are disregarded and teachers are lectured on the values of patriotism and the 'war of liberation' against the imaginary - if not paranoid - socalled 21st-century imperialism of the British and the Americans. Patriotism is not currency with which to pay one's bills; one needs the good Zimbabwean dollar to survive. This is consistent with the established wisdom of Cummins (2002), who identified remuneration, acquisitiveness and materialism as being key factors in worker inspiration and motivation. Cummins (op. cit.) further contradicts the traditional view that monetary rewards have little significance to worker happiness. For a long time now, ZimGov teacher salaries have not offered teachers a corresponding level of purchasing power (Chaudhrya, et al., 2017), Zimbabwe teachers cannot help it but compare themselves with the clique of the small multimillionaire ruling elite that accumulates personal comfort and wealth (Macleod, 2016); the only social class that can afford international medical care and travel on chartered planes paid for not in Bond Notes, but in millions of crispy mint US\$, commonly understood to come straight from the Reserve Bank of Zimbabwe (Kamhungira, 2019; Moyo, 2018; News24, 2017).

One's wellbeing is critical for one's motivation. This is also the view of Kamalian, Yaghoubi and Moloudi (2010) when they argue that a motivated employee has his/her goals aligned with those of the organisation and directs his/her in sync with the organisation's goals. Both intrinsic and extrinsic motivations are influenced by both financial and non-financial incentives 
(Kasenga \& Hurtig, 2014). Implicit in these declarations is the fact that ineffective motivation is susceptible to distraction or depletion (Ryan, 2019), as may be depicted by possible agitation and teacher strikes. Some of theorists on teacher motivation include Adams' Equity Theory. That theory suggests that teachers not only expect rewards and to enjoy an enriching/challenging job environment but also become dissatisfied when they feel unfairly treated, as seems to be the case in Zimbabwe. Concurring with that position are Maslow's (1954) and Adams' (1965) works relating to teacher salary-related wellbeing concerns.

\section{Theoretical framework}

Marx preached the unity of workers but that is not what employers like the ZimGov want to hear. According to Estanque, (2009), these employers aim for fragmented "work" as a way of disciplining what they regard as the rebelliousness of the working class. Smith, (2016) observed that, wage levels can only be settled by the continuous struggle between capital and labour, the capitalist constantly tends to reduce wages to their minimum, ... while the working man constantly presses in the opposite direction. The liberalisation of Zimbabwean education into open provision by private players and the subsequent splintering of teacher trade unions fed into the ZimGov's arrogance when faced by teachers who demanded salary-based wellbeing improvements. Teachers appear to have become more glaringly excluded and deprived than in the past due to this decentralisation and privatisation of education making teachers feel precariousness and even "neo-slavery (Estanque, 2009). This study takes a postmodernist approach in order to deconstruct some of the assumptions on teacher welfare through interrogating how Zimbabwean teachers construct their personal and collective wellbeing identity (Connolly, 1991; Christina, Waterson, Dainty \& Daniels, 2015), particularly relating to wellbeing. The ZimGov liberalised education through the Education Act of 1992 and that saw the mushrooming of many private schools as well as many teacher trade unions an apparent strategy for disuniting teachers. Teachers seem to have become easily silenced through what may be considered both covert and overt blackmail, as in intimidatory practices of alleging non-patriotism followed by wanton political abuse over fabricated or real association with opposition politics, (Majongwe, 2019).

Oppressive employers are tend to ignore the fact that, every worker has a constitutional right to indulge in either opposition politics or none at all and to further enjoy unreserved personal choices, non-disclosure and freedom from unfounded allegations without fear of victimisation. Postmodernism does not take the professional identities of these teachers as a pre-given constructed in their expressivism, as in narratives, texts, discourses, related media and coding (Christina, et al, 2015; Schram, 1993). Anecdotal reports and cursory observations seemed to suggest that these teachers are stuck in impoverishing socio-economic situations recreated to erode their salaries' buying capacities. If that was the case, then ZimGov's impoverishing welfare policies distorted teacher wellbeing class identity; a critical factor in reproducing teacher poverty (Schram, 1993) due to poor salaries; a further big factor in teacher demotivation consequential to the perceived propensity towards quarterly industrial action protests. On the other hand, a well-compensated public sector enables the government to attract, retain and motivate high-quality employees and to deliver services effectively, posits Hutton (2011). That is also the perception from Maslow's Theory of Motivation and Adam's Equity Theory to teacher salaries. 
lliya and Ifeoma (2015) and Maslow in his Theory of Motivation suggest that, among other factors, security is essential for motivation. Security here relates to social wellbeing as defined by a teacher's tolerance of his/her socio-economic situation status. Under the economic factors of motivation, a teacher becomes concerned by issues of his/her salary, which probably partly explains the Zimbabwe remuneration issues as in daily consumption, medical benefit needs and future retirement benefits (Chang, 2018). On the other hand, as an employer, ZimGov does not seem to show any inclination towards speedily resolving remuneration concerns. Poor remuneration in comparison to other college/university-trained professionals demotivates teachers, creates the general perception that the teaching profession in Zimbabwe, has been degraded into an underclass subgroup of financially stressed workers who are generally driven into debt to make ends meet (Macleod, 2016). Due to the 1992 Education Act which liberalised education employment in Zimbabwe, teaching as a profession has become a precarious profession. Educational liberalization virtually deregulated the employment of teacher recruitment as many qualified from colleges are not guaranteed of jobs, the profession is generally characterized by poverty, unemployment and underemployment (Ferreira, 2003).

\section{Methodology}

This was a qualitative research design study to investigate teachers' perceptions relating to their salary-induced wellbeing situations.

In order to obtain rich data on teacher welfare concerns, the participants were identified through snowballing in an effort to deliberately focus on only those teachers with either salaryrelated teacher welfare concerns or those known in their communities to be actively aligned to the vocal teachers' trade unions. Among the participants were four who had recently resigned from public service teaching due to welfare concerns: C4i, C5ii, C10iii and M13iv.

The snowballing sampling strategy enabled the identification of seventeen $(\mathrm{N}=17)$ teachers in total: ten ( $\mathrm{N}=10)$ from Chitungwiza District; and seven $(\mathrm{N}=7)$ from Mazowe District. Three teachers $(\mathrm{N}=3)$ from Chitungwiza and one $(\mathrm{N}=1)$ from Mazowe were no longer in government service. Only one-on-one interviews with the researcher were possible. The following table provides the sampled profiles of the participants.

\section{Table 1: Sampling Profiles}

\section{Chitungwiza District}

\begin{tabular}{|l|l|l|l|l|}
\hline & Sex & Service Years & Qualifications & Household \\
\hline C1 & M & 30 & BA, CE & 8 \\
\hline C2 & F & 26 & Dip Ed & 9 \\
\hline C3 & M & 39 & CE & 11 \\
\hline C4i & M & 10 & DE & 4 \\
\hline C5ii & F & 15 & BA, PGCE & 7 \\
\hline C6 & M & 7 & BA PGCE & 3 \\
\hline C7 & F & 8 & MSc, B.Ed, PGCE & 1 \\
\hline C8 & F & 24 & BA, PGCE & 6 \\
\hline
\end{tabular}




\begin{tabular}{|l|l|l|l|l|}
\hline C9 & F & 20 & BSc PGCE & 6 \\
\hline C10iii & F & 9 & BSc, PGCE & 7 \\
\hline
\end{tabular}

\begin{tabular}{|l|l|l|l|l|}
\hline \multicolumn{6}{|l|}{ Mazowe District } \\
\hline & Sex & Service Years & Qualifications & Household \\
\hline M11 & M & 19 & MA, BEd, PGCE & 7 \\
\hline M12 & M & 3 & Dip Ed & 1 \\
\hline M13iv & M & 8 & BA, PGCE & 5 \\
\hline M14 & M & 12 & BSc, PGCE & 1 \\
\hline M15 & F & 28 & MEd, BEd, PGCE & 9 \\
\hline M16 & F & 33 & Dip Ed & 10 \\
\hline M17 & M & 5 & Dip Ed & 1 \\
\hline
\end{tabular}

One-on-one interviews were carried out in the Chitungwiza and Mazowe Districts. With the participants' permission, after agreeing on confidentiality safeguards, interviews were personally conducted by the researchers.

The researchers digitally recorded the live interviews from the willing participants and, where applicable, gestures and emotional responses were captured and considered for data analysis. Non-verbal communication was important in this study. As much as $92 \%$ of any piece of face-to-face communication can be non-verbal, and therefore capturing different forms of communication gestures, such as tone of voice, speaking pauses, body posture, body gestures, and especially facial expressions, can communicate the speaker's attitude, emotions or intentions (Nashwa, 2017).

As each interview developed, further questions were introduced through various probing techniques. The data were stored on the researchers password-protected personal computer and analysed by tracing research objectives embedded themes: namely, salaries, wellbeing concerns, proposals and advice. These had been identified as being topical during the researcher's preliminary enquiries relating to the teachers' concerns. From the responses to these research question-based issues, further frequently appearing words from the participants' responses were also considered for additional themes during word and sentence analysis to give meaning to the responses.

An open-ended interview questionnaire was the instrument used to interrogate these perceptions on five welfare issues:

1. Salary

2. Professional community standing

3. Food and clothing

4. Pocket money

5. Emergency expenses 


\begin{tabular}{|l|l|l|l|l|}
\hline \multicolumn{6}{|l|}{ Research Questionnaire (RQ) based themes } \\
\hline Question 1 & Question 2 & Question 3 & Question 4 & Question5 \\
\hline What is working & What do you & What are your & What do you & Any advice for \\
well/not working & regard as the & current & expect from the & your \\
well for you as & issue/s with & Zdvantages & $\begin{array}{l}\text { ZimGov as a } \\
\text { a salary earning }\end{array}$ & government \\
teacher? & your salary? & $\begin{array}{l}\text { and/or } \\
\text { disadvantages } \\
\text { as a teacher? }\end{array}$ & employee? & rewards policy? \\
& & & & \\
& & & & \\
\hline
\end{tabular}

\section{Findings}

\section{Objective 1}

In response to Objective 1, Zimbabwean teachers highlighted that the main issues about their wellbeing were:

a) In a country with very high levels of unemployment, most teachers are grateful to be employed:

I am better off here doing what I like best: teaching. Besides this, what else would I do? Sell air time credit cards? (C3)

I have no clue what else I could do, you know? (M15)

I love this job but it's the comfort of it all, the decency, that I miss. That comfort is not there anymore. (C8)

I am happy to be employed. (M17)

I have been employed as a teacher all my working life. (C3)

It was great to have a job but.... (C5ii)

The above evidence of continued commitment by most of the teachers to their career was analysed within the real socio-economic context of the prevailing material welfare needs of the Zimbabwean teacher. Teachers, like all workers, except some priests, were motivated to work, among other considerations, in order to meet their basic socio-economic need for salaries (Alsiewi \& Agil, 2014). The majority loved teaching despite the government's own probable insensitivity towards teachers' welfare needs.

However, the teaching profession in Zimbabwe belonged to a monopsony labour market. More than three quarters of the teachers were employed by ZimGov without significant choice to move on to a more competitive employer (Ghilarducci, 2018). Transition into Zimbabwe's private education system was very competitive among experienced and in-demand subject 
teachers. Most Zimbabwean teachers, therefore, were servants of the monopoly employer power of ZimGov: a default mass teacher employer or the virtual sole demander of teaching labour services (Kennedy, 2012).

It is likely that the dearth of serious employer competitors within the Zimbabwean teacher employer market placed ZimGov under no pressure to improve teachers' wellbeing because ZimGov not only trained teachers but also enjoyed the first right of refusal in the teacher job market.

While teacher affective and normative commitment was confirmed as being high for the majority in the sampled participants, a few confirmed having resigned from ZimGov because they felt that their welfare needs were not adequately met on a ZimGov salary.

b) Teachers were unhappy with their low salaries:

Indeed, our salaries have been below the poverty datum line for years. ... and this government does not care, my brother. (M11)

It is just the salary that makes me angry. The salary is too low and long overtaken by the cost of living. (C1)

By the end of my first year I had nice furniture in 1979. That has not been possible for the new teachers now...no. Not any longer and for some time now. For us veterans, we can't change for new furniture like we used to do...it's unaffordable. (C3)

The current salary is not meant for adults but maybe high school kids' pocket money. (C10iii)

This sample worried that for years they had been paid below the poverty datum line, leading to unhappiness over their wellbeing experiences that pushed some teachers into selfemployment, private education teaching or work in the diaspora (Manik, 2014; Penson \& Yonemura, 2012). That stage of withdrawal started with poor student learning due to teacher absenteeism and poor preparation because of, among other reasons, teachers' low pay (World Bank, undated). This was also confirmed in the United Kingdom (UK), where teachers were certainly leaving the occupation, and pay was a confirmed factor, according to YoungPowell (2016). In Estonia, Heidmets \& Liik, (2014) acknowledged that financial rewards, as well as quality of relationships and management, are important for teachers to feel good in the workplace. As in Zimbabwe, the value of teachers' salaries in this graduate market had not kept pace with the cost of living in the UK, observed Young-Powell (op. cit.). Similarities between Zimbabwe and the UK also confirmed that a teacher could not afford to raise a family, and left the profession needing to live on - and not just survive on - a salary, posits YoungPowell (op. cit.) but that is not in any way suggesting similar economies between the two countries.

c) Some teachers resigned out of frustration with their salaries:

Could not stand it, mate. The salary was miserable. I wonder how those guys still in service survive. (C4i) 
I was financially frustrated and gave up...was a starvation salary. Could not manage and just tried other means of raising money, and it's working ...not great but much better. Now can afford fees for my children without borrowing. (C5ii)

It's not enough to be employed. We are unfairly rewarded and badly treated. Nobody listens and there are no offers. (M16)

There seems to be a deliberate effort to reduce teachers into miserable paupers on this salary. I can't raise enough for my marriage. Struggling. (M12)

How can we be paid so little? 500 Bond Notes? It's a joke, man. That is a mere 167 US dollars a month in a city where bus fare to work is a dollar one way. (C9)

The issue of salaries made me dislike my work. I became angry and I was overwhelmed daily by hatred for the job ...hurt feelings whenever some of these political elites flew out of the country for medical attention as my own medical aid was rejected by my doctor and pharmacy. I did not have the upfront cash in US dollars. You see, I have a terminal illness. I can only do with a special diet and medical support from regular doctor check-up for monitoring my condition. (C10iii)

Zimbabwean teachers were frustrated by their low salaries. The lower a person's annual income falls below a given benchmark, as in possibly the case with the Zimbabwe statistical poverty datum line, the unhappier a teacher felt (Luscombe, 2010). Teachers' low salaries harm quality of teaching, according to Garner (2015); a fact that was confirmed by the sampled teachers when some stated that they felt the urge to resign because their salaries frustrated them; they were lower than similarly qualified roles. In the UK, other roles of similar academic qualifications to teachers considered teacher salaries to be uncompetitive (Garner, 2015). Salaries were the only means by which most Zimbabwean teachers achieved their cherished wellbeing, and that was an emotional matter.

Emotional wellbeing and life evaluation (life satisfaction) of the participants was critical in how teachers analysed their purchasing power as being factors relating to what mattered most regarding teacher work-life satisfaction and wellbeing (Barr, 2018).

d) ZimGov was insincere:

This government is disingenuous. The so-called bargaining process is a mere talk shop. Nothing material has ever come out of it over the years. (C9)

I gave up and now doing my own thing at home. See, Maths is in demand and I am now doing fairly well as a private tutor. Good money. Good US dollars and not this bond nonsense. (M13iv)

It's a well-established cycle, my friend. Towards the beginning of each term, teachers threaten to strike, government offers negotiations and, after three weeks into the term, nothing tangible comes out of those negotiations. Beginning of the following term the cycle starts all over again. It's childish really. (C10iii) 
They negotiate in bad faith. They don't like teachers to live a decent life. There must be a political agenda against teachers...remember your Russian history, man. This regime does not like ideas. (C10iii)

How can a decent government treat its teachers with so much disdain? Teaching used to be respectable, you know. They only value the army, Border Gezi Youths, ClOs and the police. No. (C5ii)

No one among these teachers believed that ZimGov engaged in salary negotiations in good faith. No one remembered ZimGov being sincere in its approach to teacher salary negotiations. ZimGov's track record over teachers' wellbeing issues had produced nothing tangible over the years:

...as far as I can remember. (C3)

There is now historical evidence of ZimGov's rigidity that seemed to be fraught with intimidation towards, during and after salary negotiations. Since teachers were in search of higher pay, they engaged in negotiations with ZimGov in terms of the Zimbabwe Constitution and the Labour Act (Chapter 28:01) (the Act), but only to become frustrated by ZimGov's immoral intrusion on trade unionism. Teacher salaries paid by ZimGov had stagnated for decades as if this employer did not view teachers as value pragmatic (Kennedy, 2012). ZimGov tended to always start on a negative with threats, as quoted by Hungwe (2019) and Share (2015), and during the process neither behaved cooperatively for an efficient agreement nor attempted to establish rapport with teachers, for example, looking for areas of common agreement (Oncol, 2007). This suggested that ZimGov appeared unwilling to achieve mutual gains and instead preferred to be a rigid negotiator, who only negotiated in order to confirm that it wielded power and control over teachers' careers and work environment (Shonk, 2019).

ZimGov's insincerity during salary bargaining processes over the years was not conducive to teacher motivation and commitment. It must be confirmed that, in any society, employment rewards are critical and government sincerity should go far in promoting teacher commitment through a fair teacher reward system. Ortyoyande (2006) contrasted ZimGov's approach by arguing that fair teacher reward systems needed to be characterised by fairness and be commensurate with individual teacher effort. Therefore, anything less, as worsened by ZimGov's insincerity and lack of a transparent rewards payment system for teachers, undermined teacher motivation to work, eroded commitment and potentially reduced teacher classroom effectiveness. On the other hand, it must always be borne in mind that teachers were paid for what ZimGov wanted done: teaching the nation's children.

A well-structured compensation plan communicates corporate objectives to employees (Heskett, 2007) and this therefore leaves one wondering whether, by paying low wages, ZimGov was communicating that teachers' performance was so appallingly low that the service did not deserve reasonable compensation. Not only did this government not consider failure to provide sufficient rewards as a violation or an unjust act (Kakande, 2015) but it often characterised salary negotiations with intimidation to frustrate teachers' bargaining power and neutralise trade unionism. The participants confirmed that ZimGov habitually used the salary negotiation process to flex its strength through harassing teachers into surrendering their right to strike: 
We have been harassed several times over strike action by state security Central Intelligence Organisation Officers (CIOs) for suspected plans to strike for wages. (M17)

Our head submits a teacher attendance update to the CIO on the day of strike action. (M11)

As our representatives commence negotiations, CIOs are deployed into schools to monitor the teacher engagement in the declared industrial action. The mere presence of ClOs in our school is intimidating. (C6)

There are times when one does not trust anybody at all. (M14)

My trade union is genuine but what can APEX achieve with this deceitful Public Service Commission during these National Joint Negotiations Council meetings? (C1)

This Public Service Commission negotiates in bad faith... just to neutralise us when we are ready for a strike then they give false hope of a salary increment that they soon forget. (C9)

\section{Objective 2}

In response Objective 2, Zimbabwean teachers' perceived concerns relating to their wellbeing salary-related issues were as follows:

a) Teachers want to be paid in US\$:

Need to access cash. Only politicians have access to cash straight from the Reserve Bank. Want the right to withdraw cash amount of choice from my bank into my own pocket. (M17)

Strongly object to this Bond Notes currency. (M16)

Bond Notes are vulnerable to inflationary fluctuations against the greenback and by the way prices are ever rising when my salary has been stagnant and never matched to the basic life family needs basket. (C3)

I am baffled by the policy on access to United States dollars. Why am I unable to get them easily from my bank? Why do we have a long road to the Reserve Bank for currency that is supposed to be what we earned and the official medium of exchange in shops? (C7)

Know what? Them elites don't queue at all. It is about class, brother, and we are condemned. We do not belong. (M13iv)

b) Teachers have no purchasing power with their salaries:

Struggled to pay for my driving lessons. (M11) 
I feel it is all regrettable that I am stuck in this occupation for so long with nothing to show for it materially other than my certificate and a Monday to Friday timetable to follow. (C8)

I withdrew my daughter from a boarding school when my husband passed away. I could not afford the fees. (M15)

Cannot repair my old car. The spares are too expensive. (C1)

Struggled to buy my medicines when still in employment. (M13iv)

It's hard from one pay day to the next. Struggle to afford meat and bread. What a life! This is embarrassing. My father was a teacher and life was much better in his day as we grew up. (C9)

Filthy in debt and no hope of coming out clean soon. (C8)

Rent is too high for my family. I have repeatedly failed to get a mortgage on this salary. It's hard to save. Will most likely retire without owning a home in town. (M12)

For my family I would need at least three rooms. That is why my boys stay with my brother back in my rural home. (C8)

Zimbabwean teachers felt exploited by their employer, ZimGov, whose policy was to ignore teacher wellbeing through giving as little as possible for wages so that they could not subsist a year without employment (Kennedy, 2012). A working family, according to these teachers, must afford basic living costs. These included accommodation rent, school fees, driving lessons, daily repairs, household maintenance costs, healthcare costs and decent meals. Similar circumstances of poor salaries were highlighted by Kakande (2015), whereby staff were so poorly paid that their families were on the brink of eviction for non-payment of rent and struggled over the usual basics, including school fees for their children. Teachers must be treated like human beings, paid fairly with decent salaries to support their families (DesJardins \& McCall, 2014). ZimGov must not inflict poverty on its people but should be known for having a good reputation for removing teachers from poverty, as may be confirmed in the foregoing.

c) Teachers believe that their wellbeing is impaired by poor salaries:

I no longer afford having fun such as driving to Harare to watch football or go on holiday.... I cannot afford these things. The cost of living is way above what I can afford. (C3)

I am sometimes paranoid about my capacity to handle difficult family life situations like accidents, sickness and death because the salary is too low. (C2)

Salary is certainly inadequate. This is upsetting. (C6)

It is a life of hand to mouth on this $\$ 503$ Bond Note salary. Goods are expensive here. (M17) 
This suit is from a second-hand clothing market, man! (C1)

I have repeatedly failed to throw birthday parties for my kids or buy presents for my husband. I think I earn less than half what I am entitled to as a postgraduate and very experienced teacher. (M15)

Never serious, and lack commitment to improve our wellbeing. (M11)

I withdrew my daughter from $X$ Boarding School after her father fell sick because the medical bills and school fees were not affordable on my small salary. (C2)

The salary is too low. (M12)

My salary is just worthless. I supplement my income by rearing chickens and growing maize for a little comfort. Actually, it's like my salary supplements my income from farming. Otherwise, life is impossible on my salary. (C3)

No hope for a breakthrough with this government. There is clear class access to health. As teachers, we can't send our beloved ones to South African hospitals like the political elites do with state resources but just have to make do with these poorly resourced clinics and hospitals. These politicians fly out to better facilities in South Africa and even overseas on chartered planes. Sometimes, doctors require upfront payment from us because they don't always trust the medical aid insurance. Politicians are killing us and they do not like our children's future. (C24)

The perception among teachers is that the state's resources are not being used efficiently for the improvement of people's wellbeing. Teachers believe that there is evidence of extravagance by politicians at the expense of some workers and exploitation of sectors, such as education, in order to raise perks for the political elite. Teachers believe that the reason why the elite seeks medical attention abroad is that the resources are only available there. Teachers also worry because they believe that the resources are not being allocated evenly.

Rewarding one employee with a higher package has a negative effect on the effort of all peers (Cullen \& Perez-Truglia, 2018). That is particularly so where, as in Zimbabwe, there seems to no transparency in how state finances are managed. When teacher representatives negotiate, they are not irrational; they are uninformed (Malhotra \& Bazerman, 2007) on the actual state of the nation's finances.

Overloading rewards to the political elite was demotivating teachers as they openly debated the costs of what they allege to be some of the state's fiscal leakages as they languished on low wages. For that reason, there was strong resentment towards political elitism in Zimbabwe from this sample.

d) Living standards not commensurate with the ascribed status:

As teachers, we are starving and poor. (M15)

There are no longer affordable housing schemes for us as teachers. (C2) 
I do not qualify for a mortgage. (C6)

The glory of the teaching job is all gone. Wonder if that is by coincidence. (C9)

Touts and mini bus drivers do better than teachers. Their average daily take home is much better than this. (M17)

It is embarrassing to be a teacher. I am not living the life I thought I would live as a teacher. I miss a lot. (M12)

Life as a teacher has changed for the worse. It is pretty tough now compared to 1979 when I started as new teacher. It was respectable to be a teacher then. (C3)

Wasted time studying to be a qualified teacher to only earn about \$100 a month. (C9)

I struggle to afford basic food, have basic clothes, and my standing in the community is somewhat uncomfortable in these second-hand suits. Look at my shoe! (C6)

I am regularly without phone credit on this crappy phone I have. Look, it has a broken screen! (M14)

I can't buy extra books for my own library collection. Used to buy material for students from my pocket, you know? (C1)

I sometimes feel ashamed and regret training as a teacher but this is all I want to do. (C9)

I owe my union credit scheme some money borrowed when my wife stayed in hospital with our premature baby for nine days before discharge. (M12)

In other districts, some teachers are regularly targeted in political victimisation for strike action. Maybe we are lucky here but we are expected to make financial contributions towards political programmes like Zanu rallies. (M17)

It would be a nightmare if an accident happened because I just do not have a clue how I would deal with that without savings. It's hard to put aside a little for the unforeseeable when one earns so little a salary like I do. (M11)

I struggle to buy basics like food and decent clothes. (C7)

I am unable to pay for my children's school fees, never mind cars and beautiful mobile phones but we need those too. (C8)

As I grew up, everybody respected our teachers. They lived very decent lives with their 404 Peugeot cars. Very respectable then. I cannot say the same with my miserable life. Teaching is no long respectable. (C8) 
Teachers were concerned by their low-salary-induced poor living standards as well as safety issues relating to Zimbabwe's coercive political terrain. A salary must solve a teachers' basic needs, and failure to do so increases many feelings of dissatisfaction and unhappiness for some, (Hunger et al 2016). Wellbeing includes perceptions on personal safety issues. Teacher wellbeing was compounded by violence against teachers, and this was confirmed as being sporadic but unabated since 2002 (Manayiti \& Simbarashe, 2019; Pswarayi \& Reeler, 2012; Rweba, 2019). Commins (2018) further claimed that such types of violence could include the occupation of schools as bases of operations, assassinations of teachers and school principals as part of an overt political programme of intimidation, and threats in some countries used to subdue local communities. This affected the way in which teachers appreciated their wellbeing.

\section{Objective 3}

In response to Objective 3, Zimbabwean teachers' proposals for welfare improvements were as follows:

Government must raise our salaries. (C9)

Basic teachers' salary needs to be $\$ 1,500$. (M17)

Salary negotiations need to yield tangible results translating into improved wellbeing. (M14)

Government must address teachers' basic salary and not waste time talking about allowances. (C5ii)

\section{Objective 4}

In response to Objective 4, Zimbabwean teachers' recommendations to advise ZimGov rewards policies were as follows:

1. ZimGov's APEX to be more genuine in its approach to teacher salary negotiations.

2. Salaries be raised to $\$ 1,500.00$ in US $\$$.

3. Government to restore teachers' positions in the community.

4. Government needs to respect workers' rights, as enshrined in the Labour Relations Act, without victimisation or repercussions by the army, the police, ClOs and militias.

\section{Conclusion}

The applicability of this research to other districts and contexts must be considered with caution because this was a limited study within a specific period. Although this study confirmed that wellbeing is multidimensional among these teachers, (Hunger et al 2016), its contribution to research is that government needs to be more effective in ensuring teachers are well remunerated. Teachers have an undoubted awareness of the factors causing teachers' wellbeing discomfort, (Mendes, 2011). At the core of wellbeing needs is a reasonable salary which, for this sample, been beyond reach. While teachers are happy to be in employment, [C3, M15, C8, M17, C5ii], they are not receiving adequate salaries [11, C1, C3, C10iii, C6, 
M17, M15]. Teacher wellbeing affected teacher wellness, [C5ii, M16, M12, M13iv, C9, C4i] education [M11, M15], good financial life [C8, C1]/good house, [C8, M12, C8, C2, C6, ] as confirmed by Taveira, (2013). Each one of the participants required a fair salary where fair was achieving financial balance through a wage that had some buying power. None in this sample was happy in the way their welfare standards and concerns were handled by government's inflation laden salary and the ZimGov may be advised to further research on how best to best handle worker wellbeing concerns without politicizing salary issues where there are genuine discomforts.

\section{Authors' contribution section:}

This paper was written by Lloyd C Mabhoyi.

\section{References}

Adams JS 1965. Inequity in social exchange. In L. Berkowitz (ed.), Advances in Experimental Social Psychology, 2, 267-299. New York: NY Academic Press. https://doi.org/10.1016/S0065-2601(08)60108-2

Alsiewi AM \& Agil SOS 2014. Factors that influence Affective Commitment to teaching in Libya. IOSR Journal of Business and Management (IOSR-JBM), 16(2), ver. III, February 2014, pp 37-46. https://doi.org/10.9790/487X-16233746

Barnetson B 2010. Alberta's 2002 teacher strike: the political economy of labour relations in education. Education Policy Analysis Archives, 18(3). [Online]. Available at: $\mathrm{http}: / /$ epaa.asu.edu/epaa/v18n3/ [Accessed on: 2018.12.13] https://doi.org/10.14507/epaa.v18n3.2010

Barr S 2018. This is how much money you need to earn to be happy, according to new study. at: https://www.independent.co.uk [Accessed on: 2019.03.10]

BBC 2016. 'Zimbabwe civil servants strike over unpaid wages'. July 05, 2016. [Online]. Available at: https://www.bbc.co.uk/ [Accessed on: 2018.12.13]

Böhm-Bawerk EV 2018. The Positive Theory of Capital. London: Macmillan and Co.

Centre for Education Statistics and Evaluation (CESE) 2014. School improvement frameworks: The evidence base. Sydney: NSW Department of Education and Communities.

Chang A 2018. 'Teacher pay is falling; their health insurance costs are rising'. [Online]. Available at: https://www/vox.com [Accessed on: 2019.02.13]

Chaudhrya MS, Sabirb HM Rafi N, \& Kalyarc MN 2017. 'Exploring the relationship between salary satisfaction and job satisfaction: a comparison of public and private sector organizations.' The Journal of Commerce, 3(4), pp 1-14.

Chimhini DA 1994. 'ZIMTA's trade union role'. The Teacher's Voice in Zimbabwe, July 1994, p.11. 
Chireshe R \& Shumba A 2011. 'Teaching as a Profession in Zimbabwe: are teachers facing a motivation crisis?' $J$ Soc Sci, 28(2), pp.113-118. https://doi.org/10.1080/09718923.2011.11892935

Christina S, Waterson P, Dainty A, \& Daniels K 2015. 'A socio-technical approach to improving retail energy efficiency behaviours'. Applied Ergonomics, 47, pp. 324-335. https://doi.org/10.1016/j.apergo.2014.08.003

Claude C 2013. 'Zimbabwe: teachers warn strike action still likely'. [Online]. Available at: https://www.ei-ie.org/en [Accessed on: 28/02/2019]

Commins S 2018. Fragility, Conflict, and Violence. Washington, DC: World Bank.

Connolly WE 1991. Identity/Difference: democratic negotiations of political paradox, London, MN: University of Minnesota Press.

Cullen Z \& Perez-Truglia R 2018. 'How Much Does Your Boss Make? The Effects of Salary Comparisons'. [Online]. Available at: https://www.hbs.edu/ [Accessed on: 25/02/2019] https://doi.org/10.3386/w24841

Cummins RA 2002. 'Proxy responding for subjective well-being: a review'. International Review of Research in Mental Retardation, 25, pp. 183-207. https://doi.org/10.1016/S0074-7750(02)80009-X

DesJardins JR \& McCall JJ 2014. Contemporary Issues in Business Ethics. Boston, MA: Cengage.

Dubois A \& Gadde LE 2014. 'Systematic combining: a decade later'. J. Bus. Res, 67(6), June 2014, pp. 1277-1284. https://doi.org/10.1016/j.jbusres.2013.03.036

Eggers D \& Calegari NC 2011. 'The High Cost of Low Teacher Salaries'. New York Times, January 2019. [Online]. Available at: http://www.nytimes.com/ [Accessed on: 28/02/2019]

Ereaut G \& Whiting R 2008. What do we mean by 'wellbeing'? And why might it matter? Department for Children, Schools and Families and Linguistic Landscapes (Research Report DCSF- RW073), UK

Estanque E 2009. Labour, Social Inequalities and Trade Unionism.

RCCS Review \#0 | 2009: Issue no. 0. https://doi.org/10.4000/rccsar.88

Eyewitness News (ewn) 2019. 'Zimbabwe teachers to strike over pay as currency crisis deepens'. [Online]. Available at: https://ewn.co.za/2019/01/07/ [Accessed on: 2019.03.10]

Ferreira AC 2003. Trabalho procura justiça: as formas de resolução dos conflitos de trabalho na sociedade portuguesa. Coimbra: Faculdade de Economia da Universidade de Coimbra (Doctoral dissertation).

Forgeard, M.J., Jayawickreme, E., Kern, M.L., \& Seligman, M.E. (2011). Doing the right thing: Measuring wellbeing for public policy. International Journal of Wellbeing, 1(1). https://doi.org/10.5502/ijw.v1i1.15

Gande C 2015. 'Civil Servants Wage Freeze: government to look into individual cases'. [Online]. Available at: https://www.voazimbabwe.com [Accessed on: 2019.02.23]

Garner R 2015. 'Teachers' low salaries will harm quality of teaching, OECD warns'. [Online]. Available at: https://www.independent.co.uk/ [Accessed on: 2019.02.28] 
Gee A 2017. 'Facing poverty: academics turn to sex work and sleeping in cars'. [Online]. Available at: https://www.theguardian.com/us-news/2017/sep/28/ [Accessed on: 2019.02.28]

Ghilarducci T 2018. 'Why Wages Won't Rise When Unemployment Falls'. [Online]. Available at: https://www.forbes.com/ [Accessed on: 2019.02.28]

Ghizoni SK 2013. 'Nixon Ends Convertibility of US Dollars to Gold and Announces Wage/Price Controls'. [Online]. Available at: https://www.federalreservehistory.org [Accessed on: 2019.02.28]

Gomba C 2015. 'Why Do They Stay: factors influencing teacher retention in rural Zimbabwe'. International Journal of Instruction, 8(2), July 2015, pp. 54-68. https://doi.org/10.12973/iji.2015.825a

Goodman D 2014. '14 surprising negotiating tricks to boost your salary.' [Online]. Available at: https://business.financialpost.com [Accessed on: 2019.02.20]

Hanke SH 2019. 'Zimbabwe's Monetary Death Spiral'. [Online]. Available at: https://www.cato.org/ Accessed on: [2019.01.27]

Heidmets M \& Liik K 2014. School principals' leadership style and teachers 'subjective wellbeing at school. Problems of Education in the 21st Century, 62, 40-50.

Heskett J 2007. 'How Should Pay Be Linked to Performance?' [Online]. Available at: https://hbswk.hbs.edu/ [Accessed on: 2019.02.24]

Hunger MB Morosini MC \& Stobäus CD 2016. Teacher Quality of Life: Perspectives about $\begin{array}{lllll}\text { Their Welfare. } & \text { Creative } 2379 .\end{array}$ https://doi.org/10.4236/ce.2016.716228

Hungwe V 2019. 'Skiving teachers to face the music'. [Online]. Available at: https://www.herald.co.uk [Accessed on: 2019.03.11]

Hutton W 2011. Hutton Review of Fair Pay in the public sector: Final Report. London: http://www.nationalarchives.gov.uk/

Iliya A \& Ifeoma LK 2015. 'Assessment of Teacher Motivation Approaches in the Less Developed Countries'. Journal of Education and Practice, 6(22), pp. 10-18.

Johnson SM 1986. 'Incentives for Teachers: what motivates, what matters.' Educational Administration Quarterly, 22(3), Summer 1986, pp. 54-79. https://doi.org/10.1177/0013161X86022003003

Kakande Y 2015. Slave States: the practice of Kafala in the Gulf Arab Region. New Alresford: John Hunt Publishers Ltd.

Kamalian AR Yaghoubi NM \& Moloudi J 201). 'Survey of Relationship between Organizational Justice and Empowerment: a case study'. European Journal of Economics, Finance and Administrative Sciences, 24, pp. 165-171.

Kamhungira T 2019. 'Chiwenga back from India... blowing $\$ 500,000$ on Boeing charter plane'. [Online]. Available at: https://nehandaradio.com [Accessed on: 2019.03.08] 
Kasenga F \& Hurtig AK 2014. 'Staff motivation and welfare in Adventist health facilities in Malawi: a qualitative study'. BMC Health Serv Res, 1 November 2014, pp. 1-9. https://doi.org/10.1186/s12913-014-0486-4

Kennedy G 2012. 'Economics'. [Online]. Available at: https://www.adamsmith.org Accessed on: 2019.02 .28

Kube S Marechal A \& Puppe C 2012. 'The currency of reciprocity: gift exchange in the workplace'. American Economic Review, 2912(102), pp.1644-1662. https://doi.org/10.1257/aer.102.4.1644

Li Z 2013. Study on the Consensus Salary System for Modern Enterprises. London: Springer. https://doi.org/10.1007/978-3-642-29837-0

Lovemore N 2019. 'PTUZ, ZIMTA Announce Teachers' Strike Starting on 5 February 2019'. [Online]. Available at: https://news.pindula.co.zw. [Accessed on: 2019.03.05]

Luscombe B 2010. 'Do We Need \$75,000 a Year to Be Happy? A new study by Princeton University researchers puts a figure on happiness: $\$ 75,000$ a year.' At https://www.cnbc.com > 2017.11.20 [Accessed on: 2019.03.11]

Macleod A 2016. 'The impoverishment of the masses'. [Online]. Available at: https://www.goldmoney.com. [Accessed on: 2019.01.21]

Majongwe R 2019. 'NJNC is bogus, say teachers' unions'. [Online]. Available at: https://www.zimbabwesituation.com/news/njnc-is-bogus-say-teachers-unions/

[Accessed on: 2019.03.10]

Majongwe R 2019. 'Zimbabwe teachers continue to strike in face of threats of violence' [Online]. http://www.rfi.fr/en/africa/20190206. [Accessed on: 2019.05.10]

Malhotra D \& Bazerman MH 2007. 'Dealing with the "Irrational" Negotiator'. [Online]. Available at: https://hbswk.hbs.edu [Accessed on: 2019.03.09]

Manayiti O \& Simbarashe S 2019. 'Zanu PF activists set bases at schools'. [Online]. Available at: https://www.newsday.co.zw/ [Accessed on: 2019.03.10]

Mandel D 2017. 'The Intelligentsia and the October Revolution'. [Online]. Available at: http://www.historicalmaterialism.org/ [Accessed on: 2019.03.10]

Manik S 2014. 'We are working hand to mouth: Zimbabwean teachers' experiences of vulnerability in South Africa'. Migracijske I Etnicke Teme, 2, pp. 171-191. https://doi.org/10.11567/met.30.2.3

Maslow AH 1954. Motivation Personality. New York, NY: Harper \& Row Publishers.

McCallum F Price D Graham D \& Morrison A 2017. Teacher Wellbeing: A review of the literature. Association of Independent Schools of NSW. Sydney. At https://apo.org.au > resource-files > apo-nid201816-1133141 [Accessed on: 2019.11.12]

McMahon T 2018. 'Inflation Risk'. [Online]. Available at: https://inflationdata.com/articles/2018/05/22/inflation-risk/ [Accessed on: 2019.03.10] 
Mendes AR 2011. Saúde docente: uma realidade detectada-Em direção ao bem-estar e a realização profissional [Teachershealth: A Detected Reality-Toward the Wellbeing and Job Satisfaction]. Dissertação (de Mestrado em Educação), Porto Alegre, RS: Faculdade de Educação da PUCRS. http://repositorio.pucrs.br/

Moyo CLP 1996. 'The Role of the Zimbabwe Teachers' Association (ZIMTA) In the Professional Growth and Development of Teachers'. The Zimbabwe Bulletin of Teacher Education, 4(4), October 1996, pp.41-58.

Moyo J 2018. 'How much did the plane hired for Grace cost?' [Online]. Available at: https://www.zimetro.co.zw/ [Accessed on: 2019.03.11]

Nashwa I 2017. 'Analysing Qualitative Data using Facial Expressions in an Educational Scenario'. International Journal of Quantitative and Qualitative Research Methods, 5(3), pp. 37-50.

Nathan Associates Inc 2016. USAID strategic economic research and analysis - Zimbabwe (SERA) program wage structure and labour costs in Zimbabwe: an analysis of flexibility, competitiveness and equity. USAID.

News24 2017. 'Jet-setting Mugabe spends $\$ 3.5 \mathrm{~m}$ to charter plane to Singapore, Mexico'. [Online]. Available at: https://www.news24.com [Accessed on: 2019.03.09]

Oncol J 2007. 'Principles and Tactics of Negotiation'. Pract., 3(2), pp. 102-105. https://doi.org/10.1200/JOP.0726501

Ortyoyande JH 2006. 'The implementation of teacher education programme in Nigeria'. Journal of Education and Vocational Studies, 1(4), pp. 24-40.

Oshagbemi T 2000. 'Correlates of pay satisfaction in higher education'. International Journal of Educational Management, 14(1), pp. 31-39. https://doi.org/10.1108/09513540010310387

Penson J \& Yonemura A 2012. Next Steps in Managing Teacher Migration: Papers of the Sixth Commonwealth Research Symposium on Teacher Mobility, Recruitment and Migration. London: Commonwealth Secretariat.

Pswarayi L \& Reeler T 2012. Fragility and Education in Zimbabwe: assessing the impact of violence on education. Harare: RAU.

Ree J Menno P M., Rogers H \& Muralidharan K 2018. 'Double for Nothing? Experimental Evidence on an Unconditional Teacher Salary Increase in Indonesia'. Research Briefs in Economic Policy, 105, 21 March 2018, pp. 1-3.

Rweba R 2019. 'Zanu PF activists set up militia bases in schools, teachers in trouble'. [Online]. Available at: https://www.myzimbabwe.co.zw/ [Accessed on: 2019.03.11]

Ryan RM 2019. 'Motivation and the Organization of Human Behavior: three reasons for the reemergence of a field'. In R.M. Ryan (ed.), The Oxford Handbook of Human Motivation. Oxford: Oxford Handbooks Online. https://doi.org/10.1093/oxfordhb/9780190666453.001.0001

Schram SF 1993. 'Postmodernism policy analysis: discourse and identity in welfare policy'. Policy Science, 26, pp. 249-270. https://doi.org/10.1007/BF00999719 
Share F 2015. 'Govt pays teachers, explains deductions. . . reassures civil servants on pay . .. warns against strike action'. [Online]. Available at: https://www.herald.co.zw/ [Accessed on: 2019.03.10]

Shonk K 2019. 'Negotiation Strategies: Bernie Sanders' pragmatic approach to negotiating in the Senate'. [Online]. Available at: https://www.pon.harvard.edu/ [Accessed on: 2019.03.09]

Sibanda A 2002. 'Industrial relations in Zimbabwe today: declining social responsibility of the state'. Paper presented at the 3rd African Regional Congress of the International Industrial Relations Association (IIRA), Employment Relations in a Changing World: The African Renaissance, 6-8 March 2002, Cape Town, South Africa. [Online]. Available at: www.irasa.org.za [Accessed on: 2019.03.10]

Smith S 2016. Marxism, unions, and class struggle: the future in the present. International Socialism Review. Issue No 78. Isreview.org

Symonds PM \& Ford RT 1952. Chapter VII: Welfare of the Teacher. Review of Educational Research, 22(3), 206-211. https://doi.org/10.3102/00346543022003206

Tafirenyika M Muvundusi J \& Chiketo B 2019. 'Teachers heed calls for strike'. [Online]. Available at: https://www.dailynews.co.zw/ [Accessed on: 2019.03.10]

Taruvinga T 2018. 'Zimbabwe teachers' unions divided over government offer'. http://wwmp.org.za 2018.06.08. [Accessed on: 2019.05.12].

Taveira IMR 2013. Representações Sociais da Qualidade de Vida no Trabalho [Social Representations of Quality of Life at Work]. Curitiba: Editora CRV. le at: http://wwmp.org.za [Accessed on: 2019.05.12]. https://doi.org/10.24824/978858042716.5

Thomson K 2014. 'Well-being at work: a review of the literature'. [Online]. Available at: www.nef-consulting.co.uk/well-being-at-work [Accessed on: 2019.03.12]

United States Department of State 2003. 'US Department of State Country Report on Human Rights Practices 2002: Zimbabwe'. [Online]. Available at: https://www.refworld.org/docid/3e918c2f10.html [Accessed on: 2019.02.16]

World Bank (undated). 'Teachers'. [Online]. Available at: https://www.worldbank.org/

[Accessed on: 2019.03.08]

Xaxa V 2018. 'Schools Won't Open for the 2nd Term: teachers declare strike'. [Online]. Available at: https://news.pindula.co.zw [Accessed on: 2019.03.11]

Young-Powell A 2016. 'Are England's teachers being paid enough?' [Online]. Available at: https://www.theguardian.com [Accessed on: 2019.03.12] 


\section{Appendix 1: Questionnaire}

RQ1: What is working well/not working well for you as a salary earning teacher? RQ2: What do you regard as the issue(s) affecting teachers' welfare in Zimbabwe? RQ3: What are your current advantages and/or disadvantages as a teacher? $\mathrm{RQ4}$ : What were your expectations on joining the profession?

RQ5: Any advice for your government rewards policy?

Corresponding author: Lloyd Chaurika Mabhoyi Contact email: Imabhoyi2001@gmail.com 